\title{
Applicability of Article 6(1) ECHR
}

All provisions in the ECHR have a limited scope of application and Article 6(1) ECHR is not an exception to this rule. On contrary, the fair trial provision has long been the battlefield on which governments have claimed procedural immunity for disputes while applicants have argued that such immunities are incompatible with the principles of the rule of law. What was at stake in such cases was more than the outcome of any individual petition at the Strasbourg Court. It was the applicability of Article 6(1) ECHR to proceedings that, until that moment, were immune from international fair trial guarantees.

As a "pop-corn provision", Article 6(1) ECHR has continued to puff up and grow over time, expanding the applicability of the fair trial guarantees to a broader range of case types. As the case-law developed, the governments lost more and more battles and were ordered to enforce fair trial guarantees with respect to a large number of disputes. Looking back on more than 50 years of case-law of the ECtHR, it might be fair to argue that Article 6(1) ECHR is the provision that contributed the most to the advancement of the rule of law and individual justice in Europe.

According to the case-law, Article 6(1) ECHR may be relied on by individuals who consider that an interference with the exercise of their rights is unlawful and complain that they do not have the possibility to submit that claim to a court meeting the requirements of Article 6(1) ECHR. As the Court put it in Golder, the right to a fair trial embodies the "right to a court", of which the right of access, that is the right to institute proceedings, is one aspect. ${ }^{1}$

However, the right to a court is not absolute, as Article 6(1) ECHR applies solely for the purposes of determining civil rights and obligations or criminal charges. This apparently anodyne rule incentivized governments to argue that many of the domestic proceedings about which applicants complained fell outside the scope of Article 6(1) ECHR as they dealt neither with civil rights and obligations, nor with criminal charges. This was the case in numerous administrative proceedings challenged under Article 6(1) ECHR in Strasbourg, about which governments argued for a very long time that they did not concern neither civil rights nor criminal charges.

1 Golder v. United Kingdom, quoted above. 
What is at stake in such situations is far more important than the legal solution to a case: if the Court concludes that the proceedings at issue concern civil rights or criminal charges, it will perform its analysis and will eventually order the defending government to ensure fair trial guarantees in future disputes. However, if the Court finds that the relevant proceedings do not concern civil rights and obligations or criminal charges, it will conclude that Article 6(1) ECHR is not applicable and it will reject the application for being incompatible ratione materiae with the Convention.

The right to fair trial has not only been used by the Court for the enhancement of the individual's position when opposing a government. On the contrary, the right to a fair trial is often relied on successfully by the governments as a barrier against the jurisdiction of the ECtHR.

The present chapter is organized as follows: Section 5.1. presents the caselaw of the ECtHR concerning the disputes to which Article 6(1) ECHR is not applicable; Section 5.2. presents the case-law of the ECtHR concerning the applicability of Article 6(1) ECHR to disputes concerning "civil rights and obligation"; and Section 5.3. presents the case-law of the ECtHR concerning the applicability of Article 6(1) ECHR to disputes concerning a "criminal charge", including economic law disputes and competition law disputes.

\subsection{Maintaining Pockets of State Sovereignty}

Harris, O'Boyle, Bates and Buckley argue that "some of the more perplexing problems in the interpretation of the Convention concern the application of Article 6(1) to non-criminal cases".2 They show that in its early jurisprudence, the Court interpreted the notion "in the determination of his civil rights and obligations" as imposing a distinction between the civil and public law spheres, a distinction that "has long been significant in civil law systems for jurisdictional and other purposes and has more recently become important in UK administrative law". ${ }^{3}$ This distinction, however, is also at the origin of important difficulties for the Court because the dividing line between public and private law is more and more difficult to defend.

The claims that the Court considers as belonging to the sphere of public law, and that are therefore excluded from Article 6(1) ECHR protection are few. In Pierre-Bloch, the Court found that the right to stand for elections was

2 Harris, O'Boyle, Bates and Buckley, op. cit., p. 210.

3 Harris, O’Boyle, Bates and Buckley, op. cit., p. 211. 
a political, not a civil right and therefore that the fair trial guarantees did not extend to the applicant's case. ${ }^{4}$

In Maaouia, the same conclusion was reached as regards the expulsion of aliens. The Court held that "decisions regarding the entry, stay and deportation of aliens do not concern the determination of the applicant's civil rights or obligations". 5

In Ferrazziniv Italy, the Court found that the duty to pay tax did not concern a person's civil rights because it clearly held the nature of a public law. The Court explained that relations between the individual and the state have changed in many spheres during the 50 years which have elapsed since the convention system was put in place. One defining feature has been that state regulation increasingly intervenes in private law relations. This has led the Court to find that procedures deemed under national law as being parts of 'public law' could come within the purview of Article 6(1) ECHR if the outcomes were decisive for private rights and obligations. Moreover, the state's increasing intervention in the individual's day-to-day life, in terms of welfare protection for example, has required the Court to evaluate features of public law and private law before concluding that the asserted right could be classified as civil. ${ }^{6}$ However, the Court concluded that certain rights and obligations, such as the duty to pay tax, remain excluded from the protection offered by Article 6(1) ECHR because "they form part of the hard core of public prerogatives". ${ }^{7}$

\subsection{Applicability of Article 6(1) ECHR to "Civil Rights and Obligations"}

The current section of the book describes the case-law of the ECtHR concerning the applicability of Article 6(1) ECHR to disputes concerning "civil rights and obligations". This section covers (1) contestations of public policy decisions, (2) disputes raising land issues, (3) disputes raising concerns in relation to the right to education, (4) disputes concerning social policy decisions, (5) constitutional disputes and (6) employment disputes which have long been considered as belonging to the sphere of public law.

4 ECtHR. Pierre-Bloch v. France, application no. 24194/94, judgement of 21 Oct 1997, p. 202.

5 ECtHR. Maaouia v. France, application no. 39652/98, judgement of 5 Oct 20oo, paragraph 40.

6 ECtHR. Ferrazzini v. Italy, application no. 44759/98, judgement of 12 Jul 2001, paragraph 27.

7 Ferrazziniv. Italy, quoted above, paragraph 29. 


\subsubsection{Public Policy Decisions and Individual Rights}

In the case of Powell and Rayner the applicants' access to the domestic courts in respect of aircraft noise nuisance was denied by Section 76(1) of the UK 1982 Civil Aviation Act which set a statutory bar to this end. ${ }^{8}$ To the extent that no substantive right existed under domestic English law to obtain relief for exposure to aircraft noise, the Court held the view that there was no civil right recognized under domestic law to attract the applicability of Article 6(1) ECHR.

This idea was further developed in the case of Roche which concerned an applicant who took part in chemical weapons research after joining the British Army. ${ }^{9} \mathrm{He}$ found himself unable to apply for a service pension following health problems as Section 10 of the UK Crown Proceedings Act amounted to a procedural bar to the right of action against the Crown.

The applicant complained at the Court that his right of access to a court was violated by the English domestic authorities. The Court recognized that, while Article 6(1) ECHR secures for everyone the right to have a claim relating to his civil rights and obligations being heard before a court, it does not guarantee any particular content for those rights in the substantive law of the member states. ${ }^{10}$

The Court thus acknowledged that the basis for the qualification of a right as being "civil" should be the qualification of the right in the relevant domestic law. The Court noted in this sense that Section 10 did not remove a class of claim from the domestic courts' jurisdiction or confer immunity from liability which had been previously recognised. In fact, such a class of claims has never existed under English domestic law and it was not for an international tribunal to create it.

It is interesting to notice that even if the Court found that Article 6(1) ECHR was not applicable in the present case, it found a violation of Article $8 \mathrm{ECHR}$ in respect of the inadequate access to information about the tests performed in Porton Down. The Court found that a "positive obligation arose to provide an effective and accessible procedure enabling the applicant to have access to all relevant and appropriate information which would allow him to assess any risk to which he had been exposed during his participation in the tests". ${ }^{11}$ (emphasis added)

ECtHR. Powell and Rayner v. the United Kingdom, application no. 9310/81, judgement of 21 Feb 1990, paragraphs 34-36, Series A no. 172.

9 ECtHR. Roche v. the United Kingdom [GC], application no. 32555/96, judgement of 19 Oct 2005 .

$10 \quad$ Roche v. the United Kingdom [GC], quoted above, paragraph 116.

11 Roche v. the United Kingdom [GC], quoted above, paragraph 162. 
In Athanassoglu, the applicants complained that they were denied effective access to a court in breach of Article 6(1) ECHR. ${ }^{12}$ They complained in particular that it had not been open to them under Swiss law to seek judicial review contesting the lawfulness of a decision of the Federal Council granting a limited operating license for the Benzau II nuclear power plant.

The Court made a few important clarifications in this judgement. The Court noted that

the applicants are seeking to drive from Article $6 \S 1$ of the Convention a remedy to contest the very principle of the use of nuclear energy or at least a means for transferring from the government to the courts the responsibility for taking, on the basis of technical evidence, the ultimate decision on the operation of individual nuclear power stations. ${ }^{13}$

The Court further observed that Swiss law empowered the applicants to partially contest the extension of the operating license of the power plant and to initiate ordinary civil proceedings for nuisance and de facto expropriation. However, "how best to regulate the use of nuclear power is a policy decision for each Contracting State to take according to its democratic processes. Article $6 \S 1$ cannot be read as dictating any one scheme over another". ${ }^{14}$

The Court concluded that the proceedings at issue were indeed important for the general question of extension of the operating license, but not for the determination of any of the applicants' civil rights and obligations. The case was thus declared inadmissible under Article 6(1) ECHR.

Domestic administrative proceedings have raised issues concerning the applicability of Article 6(1) EC H R. In fact, for many years Governments insisted that domestic administrative proceedings did not concern civil rights or obligations and that they fell outside the scope of application of Article 6(1) ECHR.

In a case against Turkey, the applicants successfully contested the granting of permits to operate a gold mine due to the environmental threats posed by the mining activity. Despite the existence of a final judicial decision prohibiting the mining activity, the company at issue managed to circumvent it and to continue its actions. ${ }^{15}$

ECtHR. Athanassoglou and Others v. Switzerland [GC], application no. 27644/95, judgement of 6 Apr 2000.

13 Athanassoglou and Others $v$. Switzerland [GC], quoted above, paragraph 53.

14 Athanassoglou and Others $v$. Switzerland [GC], quoted above, paragraph 54.

15 ECtHR. Taşkin and Others v. Turkey, application no. 46117/99, judgement of 10 Oct 2004. 
The Turkish Government defended itself, arguing that the risks relied on by the applicants were only probable and hypothetical and did not therefore concern civil rights and obligations.

The Court started its analysis noting that, in contesting the mining permit, the applicants attempted to obtain adequate protection of their physical integrity against the risk entailed by the operation of the gold mine under discussion.

The Court than noted that the risk presented by the gold mine had been clearly assessed by the domestic courts when cancelling the mining permit and that the proceedings instituted by the applicants were the single means under Turkish legislation to protect their right to live in healthy and balanced environment. The Court also noted that the outcome of the proceedings before the administrative courts, taken as a whole, were relevant for the applicants' civil rights. ${ }^{16}$

In the case of Alatulkkila and Others $v$ Finland, the applicants were owners of water areas in Finland. ${ }^{17}$ In 1996, the Finnish-Swedish Frontier Rivers Commission prohibited all fishing of salmon and sea trout in the relevant waters during 1996 and 1997. Some of the applicants received compensation for the economic losses suffered due to the imposed restrictions.

The applicants complained under Article 6(1) ECHR about the impossibility to review the decision of the Finnish-Swedish Frontier Rivers Commission by a tribunal.

The Finish Government contested the applicability of Article 6(1) ECHR to the proceedings involving the decision of the Finnish-Swedish Frontier Rivers Commission, arguing that the right to fish belonged to the state, not to the applicants.

The Court held that "although Article 6 cannot guarantee a right of access to a court with power to invalidate or override a law enacted by the legislature, it must examine the direct effect of the decisions of the Finnish-Swedish Frontier Rivers Commission which prohibited fishing under the powers bestowed on them by various decrees". 18

In concluding that the right to fish was a civil right, the Court noted that prior to the ban, the applicants enjoyed an undisputed right to fish salmon and sea trout. Also, the Court attached a particular importance to the fact that

16 Taşkın and Others $v$. Turkey, quoted above, paragraphs 131-134.

17 ECtHR. Alatulkkila and Others v. Finland, application no. 33538/96, judgement of 28 Jul 2005.

18 Alatulkkila and Others $v$. Finland, quoted above, paragraph 5 o. 
some of the applicants received compensation for loss of income as professional fishermen arising from their inability to continue to fish.

In the case of $X$, the applicant complained of state negligence in relation to blood transfusions that infected him with the HIV virus. ${ }^{19} \mathrm{He}$ complained at the Court about the length of the proceedings in which he was involved.

The French Government argued that the health policy contested by the applicant was covered by public law provisions and was not, therefore, covered by the Article 6(1) ECHR guarantees.

Holding that the outcome of the negligence proceedings initiated by the applicant were decisive for his private rights and obligations, the Court concluded that Article 6(1) ECHR was applicable and that, furthermore, the reasonable time of these proceedings had been exceeded. ${ }^{20}$

Further explanations concerning the issue of civil rights and obligations were offered by the Court in the case of Wós, in which the applicant was subjected to forced labour during the Second World War on the territory of occupied Poland. ${ }^{21}$

In 1991, an agreement was signed between the Federal Republic of Germany and the Republic of Poland addressing the issue of Polish nationals persecuted by the Nazi regime. The applicant applied to the Polish-German Reconciliation Foundation for compensation on account of his forced labour.

Upon the modification of the admissibility rules concerning the granting of compensations sponsored by the Government of the Federal Republic of Germany, the applicant applied for an increase of the amount initially received. When his application was declared inadmissible in law by the Polish Supreme Administrative Court, the applicant complained under Article 6(1) ECHR that he did not have access to a court in respect of his claim raised before the Polish-German Reconciliation Foundation.

The Polish Government argued that Article 6(1) ECHR was not applicable to the present case due to the fact that the compensation granted by the Foundation was incidental in nature, had a symbolic rather than real economic value and was in no way similar to welfare allowances.

The Court noted that

there is no general obligation under the Convention for States to compensate wrongs inflicted in the past under the general cover of State authority. However, if such a compensation scheme were to be established,

\footnotetext{
19 ECtHR. Xv. France, application no. 18020/91, judgement of 31 Mar 1992, Series A no. 234-C.

$20 \quad X v$. France, quoted above, paragraph 49.

21 ECtHR. Wośv. Poland, application no. 2286o/o2, judgement of 8 Jun 2006.
} 
the Court observed that substantive regulations which determined the eligibility criteria for any compensation would in principle fall outside the Court's jurisdiction, unless the relevant criteria were manifestly arbitrary or blatantly inconsistent with the fundamental principles of the Convention. On the other hand, the Court noted that it could not be excluded that some procedural issues - related to the application of those eligibility criteria to the facts of individual cases - could arise. In other words, once a compensation scheme is put in place by a Government or with a Government's consent, and regardless of the nature of the respective benefits, issues of compliance with Article $6 \S 1$ or Article 1 of Protocol No. 1 may arise. ${ }^{22}$

To conclude, the case-law described in the section above concerns cases in which individuals were contesting public policies. The ECtHR drew attention to the fact that, whereas Article 6(1) ECHR can be relied when individuals have been personally affected by the contested policies, the situation is radically different when individuals are using Article 6(1) ECHR to contest policy ipso facto. In the latter case, Article 6(1) ECHR remains inapplicable.

\subsubsection{Land Issues}

In the case of Ortenberg, the applicant was a house owner. ${ }^{23}$ Following the decision of the district council to adopt a land-use plan and a development plan that designated as building land an area adjoining the applicant's land, she challenged the lawfulness of these actions and complained about the nuisance that would be caused.

She complained that neither the Austrian Constitutional Court, nor the administrative court were "tribunals" for the purpose of Article 6(1) ECHR. The Austrian Government argued that the neighbours' right to object to building plans was a public law right, guaranteed by public law statutes and that, consequently, Article 6(1) ECHR did not apply to the present case.

The Court pointed out that Article 6 applies where the subject-matter of an action is pecuniary in nature and is founded on an alleged infringement of rights which are likewise pecuniary or where its outcome is decisive for private rights and obligations.

The Court noted that despite the fact that the applicant challenged a public law act, her motivation was to protect her pecuniary rights. More precisely, by

\footnotetext{
22 Wośv. Poland, quoted above, paragraph 72.

23 ECtHR. Ortenberg v. Austria, application no. 12884/87, judgement of 25 Nov 1994, Series A no. 295-B.
} 
challenging the building plans, she intended to protect her private property and to avoid the decrease of its market value. Thus, the close link between the proceedings brought by the applicant and the consequences of their outcome for her property meant that the right under discussion was a "civil" right and that Article 6 was applicable. ${ }^{24}$

A similar issue arose in the case De Geouffre de la Pradelle whose property had been declared an area of outstanding beauty and public interest. ${ }^{25} \mathrm{Mr}$ de Geouffre de la Pradelle could not challenge the administrative decision at issue due to the fact that it was notified to him after the deadline for lodging complaints had expired. He complained under Article 6(1) ECHR that he has been deprived of his right of access to a court due to the uncertainty prevailing in French legislation as to the classification of decisions to designate places of interest.

Despite the fact that the French Government acknowledged that the decisions to designate places of outstanding beauty are sui generis administrative acts, it did not argue that Article 6(1) ECHR was inapplicable in such cases.

In the present case, the Court found a violation of Article 6(1) ECHR on the grounds that the system was not sufficiently coherent and clear and that the applicant did not have a practical, effective right of access to the Conseil d'Etat. $^{26}$

In conclusion, land dispute generate many cases at the ECtHR. The right to a fair trial is often invoked in these cases together with the right to property. Such cases offered the ECtHR the opportunity to reason that pecuniary rights are linked to the "civil rights and obligations" as guaranteed by Article 6(1) ECHR. In addition, many land disputes brought at the ECtHR concerned lack of effective remedy at the domestic level.

\subsubsection{Right to Education and Detention Issues}

Interesting issues concerning the applicability of Article 6(1) ECHR have arisen in relation to the right to education. In the case of André Simpson, the Commission held that Article 6 was inapplicable to proceedings concerning the laws on education due to the fact that they fell within the public law domain, had no private law analogy and had no repercussions on private rights and obligations. ${ }^{27}$

24 Ortenberg v. Austria, quoted above, paragraph 28.

25 ECtHR. De Geouffre de la Pradelle v. France, application no. 12964/87, judgement of 16 Dec 1992, Series A no. 253-B.

26 De Geouffre de la Pradelle v. France, quoted above, paragraph 35.

27 ECtHR. Simpson $v$. the United Kingdom (dec.), application no. 14688/89, judgement 4 Dec 1989. 
Almost 20 years later, the ECtHR reached a different conclusion in a case in which the applicant could not be enrolled at a University due to the fact that she refused to provide identity pictures without wearing a headscarf. ${ }^{28}$ At the Court, the applicant complained about the unfairness of the administrative proceedings before the Supreme Administrative Court.

The Court highlighted, first of all, that the public law aspect of a regulation did not suffice to exclude the right to education from the category of civil rights and obligations. The Court also stated that "where a State confers rights which can be enforced by means of a judicial remedy, these can, in principle, be regarded as civil rights within the meaning of Article $6 \S 1$ 1.29

The Court has also noted that the applicant did not deal with the public authorities as holders of discretionary powers, but merely as providers of a public service. Lastly, the Court noted the importance of the applicant's right to continue her higher education. ${ }^{30}$

In a case against Italy, the applicant, who was convicted for mafia-related crimes, was assigned by the prison authorities to a detention regime with an increased surveillance level. He was unable to challenge this assignment due to the fact that the measure was a discretionary act of the prison authorities.

In deciding whether the limitations imposed on the applicant's freedom due to the special detention regime were civil rights, the Court relied on the argumentation of the Italian Constitutional Court that jurisdictional review was particularly important when administrative authorities are entitled to modify the detention regime of convicted persons. ${ }^{31}$

To conclude, access to education and the civil rights of detained persons are issues that have initially been considered belonging to public law. However, due to the developments at the domestic level - which allowed for judicial review of these matters - the ECtHR evolved its case-law to argue that access to education and the civil rights of detainee are covered by Article 6(1) ECHR.

\subsubsection{Social Policy and Individual Rights}

Important principles concerning the applicability of the right to a fair trial were established in the case of Feldbrugge, in which the applicant complained about the fact that she did not receive a fair hearing by a tribunal in the determination of her right to a sickness allowance. ${ }^{32}$ The Court acknowledged that

28 ECtHR. Emine Araç v. Turkey, application no. 9907/o2, judgement of 23 Sep 2008.

29 Emine Araç v. Turkey, quoted above, paragraph 21.

30 Emine Araç v. Turkey, quoted above, paragraph 24.

31 ECtHR. Musumeci v. Italy, application no. 33695/96, judgement of 11 Jan 2005.

32 ECtHR. Feldbrugge v. the Netherlands [GC], application no. 8562/79, judgement of 29 May 1986. 
this was the first time it had dealt with the field of social security and more specifically, with the applicability of Article 6 to disputes concerning health insurance schemes.

The Court pointed out that under Dutch legislation, the right to health insurance was indeed a public law right. The Court highlighted that

there exists great diversity in the legislation and case-law of the Member States of the Council of Europe as regards the juridical nature of the entitlement to health insurance benefits under social security schemes, that is to say as regards the category of law to which such entitlement belongs. Some States - including the Netherlands - treat it as a public-law right, whereas others, on the contrary, treat it as a private-law right; others still would appear to operate a mixed system. What is more, even within the same legal order differences of approach can be found in the case-law. Thus, in some States where the public-law aspect is predominant, some court decisions have nonetheless held Article $6 \S 1$ to be applicable to claims similar to the one in issue in the present case. Accordingly, there exists no common standard pointing to a uniform European notion in this regard..$^{33}$

The Court then went on to analyse the public law features and the private law features of the health insurance scheme in the Netherlands and to compare them. The health insurance scheme in the Netherlands displayed three features that justified its qualification as public law and therefore its exclusion from the realm of civil rights: (1) the character of the legislation, (2) the compulsory nature of the insurance and (3) the assumption by the state of the responsibility for social protection. ${ }^{34}$

On the other hand, the Court also identified three private law features that defended the health insurance scheme as falling under the civil head of Article 6(1) ECHR: (1) the personal and economic nature of the asserted right, (2) the connection with the contract of employment and (3) the affinities with insurance under the ordinary law. ${ }^{35}$

Upon balancing the public law and private law features, the Court concluded the latter to be predominant: "none of these various features of private law is decisive on its own, but taken together and cumulatively they confer on

33 ECtHR. Feldbrugge v. the Netherlands [GC], quoted above, paragraph 29.

34 ECtHR. Feldbrugge $v$. the Netherlands [GC], quoted above, paragraphs $31-35$.

35 ECtHR. Feldbrugge v. the Netherlands [GC], quoted above, paragraphs $36-39$. 
the asserted entitlement the character of a civil right within the meaning of Article 6 para. 1 (art. $6-1$ ) of the Convention which was thus applicable". ${ }^{36}$

Almost ten years after the Court delivered its judgement in Feldbrugge, the issue concerning the applicability of Article 6(1) ECHR to welfare benefits was brought before the ECtHR again. In the case of Salesi, the applicant complained about the length of the proceedings concerning a disability allowance. ${ }^{37}$

The Italian Government maintained that, since the state financed the scheme and since the entitlement to the disability allowance was not dependent on the payment of contributions, the subject was exclusively a public law matter.

The Court held that welfare assistance was different from the issue treated in the Feldbrugge case, namely social insurance, but did not choose to perform the long and detailed analysis provided in Feldbrugge. Three issues seemed to be of importance for the Court in the present case. First, state intervention was not sufficient to establish that Article 6(1) ECHR was inapplicable. Second, the applicant was not affected by her relations with the administration's exercising of discretionary powers. On the contrary, Mrs Salesi was suffering an interference with her means of subsistence and was claiming an economic right guaranteed by the Italian Constitution. Last, the Court acknowledged that disputes similar to that of the applicant came within the jurisdiction of ordinary courts.

It is interesting to note that, while in Feldbrugge the applicability of Article 6(1) ECHR was decided by a vote of ten to seven, it was unanimously affirmed in Salesi that Article 6(1) ECHR was applicable to disputes concerning welfare benefits.

In another case against the Netherlands, the applicants - who were running a physiotherapy practice - failed to pay social contributions under the Health Insurance Act due to the fact that they were contributors to private funds. ${ }^{38}$

Since this was the first time the Court had to rule on the applicability of Article 6(1) ECHR to disputes concerning contributions to a social security scheme, the Government of the Netherlands insisted that the contributions in question were akin to taxation and therefore did not fall within the concept of civil rights and obligations.

On the substance of the case, the Court applied the Feldbrugge test and concluded that when balancing the public law features of social security schemes (the character of the legislation, the compulsory nature of the schemes and the

36 ECtHR. Feldbrugge v. the Netherlands [GC], quoted above, paragraph 40.

37 ECtHR. Salesi v. Italy, application no. 13023/87, judgement of 26 Feb 1993.

38 ECtHR. Schouten and Meldrum v. the Netherlands, application no. 190o6/91, judgement of og Dec 1994. 
assumption of the state) against their private law features (the personal and economic nature of the right, the link between the social insurance schemes and the contract of employment and the similarity between the social security schemes and the contract of employment), the latter features prevailed. The Court concluded that

the relative cogency of the features of public and private law present in the instant cases leads the Court to find that the private-law features are of greater significance than those of public law. On balance, the disputes in issue are to be regarded as having involved "the determination of civil rights and obligations" and Article $6 \S 1$ is therefore applicable. ${ }^{39}$

In conclusion, as the case-law described above indicates, social policy has been defended for a long time by European governments as public law, falling outside Article 6(1) ECHR. Unlike the land issues described in Section 5.2.2. above, the ECtHR did not rely solely on the pecuniary interests involved. The Court provided in-depth analysis of the domestic legislation and progressively reached the conclusion that the private law features of social policy legislation were determinant for the applicability of Article 6(1) ECHR.

\subsubsection{Constitutional Disputes}

Constitutional disputes offered another opportunity to consider the breadth of the applicability of Article 6(1) ECHR. In the case of Ruiz-Mateos the applicants lost their property as a result of an expropriation law. ${ }^{40}$ During the domestic proceedings contesting the expropriation, a preliminary question was referred to the Constitutional Court. As it appeared, the preliminary question proceedings lasted for two years, contributing thus to the unlawful extension of the proceedings. In addition, the applicants complained that the counsel for the state - their opponent in the expropriation proceedings - was able to submit written observations to the Constitutional Court, whereas they were not allowed to do so because they lacked locus standi.

The Spanish Government, joined by the German and the Portuguese Governments, insisted that Article 6(1) ECHR was not applicable to proceedings before the Constitutional Court by reason of their nature, structure and jurisdiction. They highlighted that the decision in the present case "would be

39 Schouten and Meldrum v. the Netherlands, quoted above, paragraph 6o.

$40 \quad$ ECtHR. Ruiz-Mateos v. Spain [GC], application no. 12952/87, judgement of 23 Jun 1993. 
of great significance to those other Member States of the Council of Europe which have a constitutional court". 41

The Court disagreed and acknowledged by eighteen votes to six that - leaving aside the abstract question of the applicability of Article 6(1) ECHR to constitutional courts - in the case at issue, there was a close link between the subject matter of the expropriation proceedings and the constitutional proceedings. More precisely, only if the Constitutional Court had declared null and void the expropriation law on the basis of which the applicants' goods had been expropriated, should the civil courts have allowed the applicants' claims. The Court held that

in the present case, the civil and constitutional proceedings even appeared so interrelated that to deal with them separately would be artificial and would considerably weaken the protection afforded in respect of the applicants' rights. The Court notes that by raising questions of constitutionality, the applicants raised were using the sole - and indirect - means available to them of complaining of an interference with their right to property. ${ }^{42}$

Aside from the novelty introduced by this judgement concerning the principle of the equality of arms in constitutional proceedings, the case is also known for the roiling dissenting opinions expressed in it.

Judge Thor Vilhjalmsson argued that the Court "cannot demand that access to the Constitutional Court in Spain be regulated in a specific way as is required by the majority of our Court".43

Judge Matscher wrote:

While I deplore the clearly unsatisfactory legal position in the case before us, it is not for the Convention organs to "allow" the applicants' claims by having recourse to Article 6 in order to remedy the situation under domestic law, which is undoubtedly deficient from the point of view of the general principles of law, but not contrary to the Convention. ${ }^{44}$

Judge Matscher criticised the reference and use of such notions like "close link" and "so interrelated" for the purpose of extending excessively the applicability

41 Ruiz-Mateos v. Spain [GC], quoted above, paragraph 56.

42 Ruiz-Mateos v. Spain [GC], quoted above, paragraph 59.

43 Dissenting Opinion of Judge Thor Vilhjalmsson, Ruiz-Mateos v. Spain [GC], quoted above.

44 Dissenting Opinion of Judge Franz Matscher, Ruiz-Mateos v. Spain [GC], quoted above. 
of Article 6(1) ECHR and concluded that such tendencies "result inevitably in the limitation of the substance of the procedural guarantees contained therein in a way which is scarcely compatible with the aim of the provision". 45

Judge Pettiti, joined by Judges Lopes Rocha and Ruiz-Jarabo Colomer, insisted that raising objections of constitutionality should not confer upon individuals the status of "parties" to the proceedings because the constitutional procedure was an institutional debate that excluded individuals.

The Ruiz-Mateos judgement concerned constitutional referrals lodged in parallel to the main proceedings. Later cases have been brought to the Court concerning constitutional appeals lodged by applicants after the exhaustion of the ordinary proceedings.

In Krcmar and Others, the applicants complained that they did not have a fair hearing before the Constitutional Court as the Court based its decision on documents that were not presented during the public hearing and were not shown to or discussed with the parties. ${ }^{46}$

The Czech Government did not dispute the applicability of Article 6(1) ECHR to the merits of the case. The Court then unanimously concluded that the applicants' restitution claim was of a pecuniary nature and that Article 6 was applicable to proceedings before Constitutional Courts.

It can be thus concluded that, during a period of ten years, the Court's view as to the applicability of Article 6(1) ECHR to constitutional disputes has radically changed. After an initial period of deeming constitutional disputes incompatible with Article 6(1) ECHR, the Court accepted, against a vocal minority, that when a close link existed between the ordinary civil proceedings and the constitutional proceedings, the latter were "civilized" and Article 6(1) ECHR became thus applicable. Henceforth, the issue remained undisputed in Strasbourg. This is due to the force of the judicial precedent in the Court's caselaw, but also to the fact that the minority judges were replaced with new judges holding new ideas about the applicability of Article 6(1) ECHR.

\subsubsection{Employment Disputes}

The case-law concerning employment of civil servants is a prime example of how the Court transitions from defining a field of law as falling outside the guarantees offered by Article 6(1) ECHR to acknowledging the contrary.

Initially, the Court considered that Article 6(1) ECHR was incompatible with disputes relating to the recruitment, careers and termination of service of civil

45 Dissenting Opinion of Judge Franz Matscher, Ruiz-Mateos v. Spain [GC], quoted above.

46 ECtHR. Krcmar and Others v. the Czech Republic, application no. 35376/97, judgement of 3 Mar 200o. 
servants. ${ }^{47}$ Slowly, however, the Court recognized the economic nature of the rights involved in an employment dispute and used this as an argument to extend the legal protection afforded by Article 6(1) ECHR to them.

To reach this conclusion, the Court first distinguished between the situations in which employment disputes involved the exercise of discretionary power of the state - such as selection or termination of contracts of civil servants - from the cases in which the applicants had claims of a purely pecuniary nature, such as disability entitlements related to the service performed. ${ }^{48}$

Later, the Court acknowledged that the absence of discretionary power and the economic nature of the dispute were difficult criteria to apply and left room for arbitrariness. Therefore, in Pellegrin the Court proposed a functional criterion, based on the nature of the employee's duties and responsibilities. ${ }^{49}$ The Court noted that

in each country's public-service sector certain posts involve responsibilities in the general interest or participation in the exercise of powers conferred by public law. The holders of such posts thus wield a portion of the State's sovereign power. The State therefore has a legitimate interest in requiring of these servants a special bond of trust and loyalty. On the other hand, in respect of other posts which do not have this "public administration" aspect, there is no such interest. ${ }^{50}$

The police and armed forces belong to the group of civil servants exercising public law powers and Article 6(1) ECHR does not apply to trials contesting their employment.

The post-Pellegrin case-law showed that the functional criterion was just as difficult to apply in practice as the previous criteria. In addition, it was a source of confusion and uncertainty. Consequently, the Court further developed its jurisprudence on the applicability of Article 6(1) ECHR to employment disputes.

In Vilho Eskelinen and Others, the applicants were policemen who lost their entitlement to a remote-area allowance following a collective agreement. ${ }^{51}$

47 ECtHR. Massav. Italy, application no. 14399/88, judgement of 24 Aug 1993, Series A no. 265B, paragraph 26.

48 ECtHR. Francesco Lombardo v. Italy, application no. 11519/85, judgement of 26 Nov 1992, Series A no. 249-B.

49 ECtHR. Pellegrin v. France, application no. 28541/95, judgement of 8 Dec 1999.

50 Pellegrin v. France, quoted above, paragraph 65.

51 ECtHR. Vilho Eskelinen and Others v. Finland [GC], application no. 63235/oo, judgement of 19 Apr 2007. 
They contested this decision before the domestic authorities, but lost the case. Upon lodging their application with the Court, the applicants complained about the length of their domestic proceedings that lasted for more than seven years and about the lack of an oral hearing.

The Court, sitting as Grand Chamber, took the opportunity to introduce a new criterion for deciding whether Article 6(1) ECHR was applicable to the applicants' employment dispute. Cognizant of its previous case-law, the Court recognized the state's interest in controlling access to a court for a certain category of staff. However, it was

primarily for the Contracting States, in particular the competent national legislature, not the Court, to identify expressly those areas of public service involving the exercise of the discretionary powers intrinsic to State sovereignty where the interests of the individual must give way. The Court exerts its supervisory role subject to the principle of subsidiarity. If a domestic system bars access to a court, the Court will verify that the dispute is indeed such as to justify the application of the exception to the guarantees of Article 6. If it does not, then there is no issue and Article $6 \S 1$ will apply. ${ }^{2}$

Vilho Eskelinen and Others established a presumption that Article 6(1) ECHR applied to all disputes involving civil servants. Therefore, it was for the government to prove that a civil servant is barred under domestic law from bringing an employment dispute before a domestic court and that the prohibition itself is justified..$^{53}$

This jurisprudence was put to the test in a recent case concerning an employee of the Ministry of Internal Affairs of Bulgaria responsible for counterintelligence and recruitment of secret agents. ${ }^{54}$ In this case, the applicant's superior attempted unsuccessfully to dismiss him on disciplinary grounds. He then asked the applicant to sit a psychological examination which concluded that the applicant was not fit to work for the Ministry of Internal Affairs. The applicant was dismissed from his position due to the unfavourable results of the psychological test. He unsuccessfully challenged this decision before the domestic courts. The domestic courts rejected the applicant's action on the ground that the psychological test performed by the Ministry's Institute was incontrovertible proof of fitness to work for the Ministry and that they could

$5^{2} \quad$ Vilho Eskelinen and Others v. Finland [GC], quoted above, paragraph 61.

53 Vilho Eskelinen and Others v. Finland [GC], quoted above, paragraph 62.

54 ECtHR. Fazliyskiv. Bulgaria, application no. 40908/o5, judgement of 16 Apr 2013. 
not replace their findings with the conclusions of the assessment at issue. Due to the classified nature of the case, the applicant had no access to the conclusions of the psychological assessment and to the judicial decisions adopted in his case.

The Court considered that Article 6(1) ECHR was applicable, despite the fact that the applicant was an officer in the National Security Directorate of the Ministry of Internal Affairs and that the dispute he sought to resolve concerned his dismissal from that post. Bulgarian legislation allowed judicial review of the dismissal of officers employed by the Ministry of Internal Affairs and the applicant was able to challenge his dismissal at the Supreme Administrative Court despite the national security interests involved. ${ }^{55}$

To conclude, employment disputes involving civil servants have been considered belonging to public law for a long time. The consequence was that the parties to employment disputes did not benefit from fair trial guarantees, such as the right to be heard, equality of arms and the right to an effective remedy. The fact that the government was a party to an employment dispute was not sufficient to maintain the dispute in the realm of public law. It thus became established case-law that Article 6(1) ECHR was applicable to employment disputes.

\subsection{Applicability of Article 6(1) ECHR to "Criminal Charges"}

The current section of the book describes the case-law of the ECtHR concerning the applicability of Article 6(1) ECHR to disputes concerning "criminal charges". This section covers (1) disputes concerning disciplinary proceedings, (2) disputes concerning petty offences, (3) disputes concerning economic offences and (4) competition law disputes.

\subsubsection{Disciplinary Proceedings}

The Court analysed for the first time the issue of "criminal charge" in the case Engel and others. ${ }^{56}$ The case concerned military disciplinary proceedings initiated against the applicants. The Dutch Government argued that the disciplinary proceedings brought against the applicants concerned neither their "civil rights and obligations" nor "a criminal charge". The Court acknowledged that

55 Fazliyskiv. Bulgaria, quoted above, paragraphs $51^{-55}$.

$56 \quad$ Engel and others $v$. the Netherlands, quoted above. 
all the Contracting States make a distinction of long standing, albeit in different forms and degrees, between disciplinary proceedings and criminal proceedings. For the individuals affected, the former usually offer substantial advantages in comparison with the latter, for example as concerns the sentences passed. Disciplinary sentences, in general less severe, do not appear in the person's criminal record and entail more limited consequences. It may nevertheless be otherwise; moreover, criminal proceedings are ordinarily accompanied by fuller guarantees. ${ }^{57}$

Understanding the linguistic conundrum posed by proceedings that would be criminal in nature, but named to be disciplinary, the Court went on to define what has become one of the most important concepts in its case-law the autonomy of concepts. The Court noted that the Convention allowed the member states, "in the performance of their function as guardians of the public interest, to maintain or establish a distinction between criminal law and disciplinary law, and to draw the dividing line, but only subject to certain conditions".58

The opposite choice, however, would be subject to stricter rules. The Court explained:

If the Contracting States were able at their discretion to classify an offence as disciplinary instead of criminal, or to prosecute the author of a "mixed" offence on the disciplinary rather than on the criminal plane, the operation of the fundamental clauses of Articles 6 and 7 would be subordinated to their sovereign will. A latitude extending thus far might lead to results incompatible with the purpose and object of the Convention. The Court therefore has jurisdiction, under Article 6 (...) to satisfy itself that the disciplinary does not improperly encroach upon the criminal..$^{59}$

The Court then moved to the three criteria for determining the content of the autonomous "criminal charge". The first element is the classification in the domestic legal system, which should serve only as a starting point and should have a formal and relative value. The second element is the nature of the offence, and the third element is the degree of severity of the penalty that the person concerned risks incurring. ${ }^{60}$

57 Engel and others v. the Netherlands, quoted above, paragraph 80.

58 Engel and others $v$. the Netherlands, quoted above, paragraph 81.

59 Engel and others $v$. the Netherlands, quoted above, paragraph 81.

6o Engel and others $v$. the Netherlands, quoted above, paragraph 82. 
On the facts of the Engel and others case, the Court noted that the maximum penalty that the applicants could have incurred was arrest lasting from two to four days and three- or four-months' committal to a disciplinary unit. The Court concluded that such "charges" attracted the applicability of Article 6 because their aim was the imposition of serious punishments involving deprivation of liberty. ${ }^{61}$

The case of Ezeh and Connors concerned the applicability of Article 6 to prison discipline proceedings and, more precisely, whether prison disciplinary proceedings can be deemed to constitute a "criminal charge".62

The Court analysed the three Engel criteria and concluded that the factors taken into consideration for the analysis "even if they were not to themselves sufficient to lead to the conclusion that the offence with which the applicants were charged are to be regarded criminal for Convention purposes, clearly give them a certain colouring which does not entirely coincide with that of a purely disciplinary matter". 63

Relying on the principle defined in Stafford concerning the need "to look beyond the appearances and the language used and concentrate on the realities of the situation", the Court found that prisoners were detained beyond the release date as a consequence of the disputed disciplinary proceedings, which were legally unconnected to the original conviction and sentence. ${ }^{6465}$

A long-standing tradition in Europe distinguished between criminal law and disciplinary law, whereas disciplinary law was deemed more efficient, having less serious consequences for the accused person and guaranteeing less fair trial safeguards. The ECtHR took a serious stance against this practice, reasoning that Article 6(1) ECHR should be applicable whenever individuals were affected by the proceedings at issue.

\subsubsection{Petty Offences}

Petty offences are another issue that produced a considerable amount caselaw under Article 6(1) ECHR. In the case of Adolf, the Court further developed the Engel criteria. ${ }^{66}$ The case concerned a criminal complaint lodged against

\footnotetext{
61 Engel and others $v$. the Netherlands, quoted above, paragraph 85 .

62 ECtHR. Ezeh and Connors v. the United Kingdom [GC], application nos. 39665/98 and 40o86/98, judgement of 9 Oct 2003 .

63 Ezeh and Connors v. the United Kingdom [GC], quoted above, paragraph 106.

64 ECtHR. Stafford v. the United Kingdom [GC], application no. 46295/99, judgement 28 May 2002.

65 Ezeh and Connors $v$. the United Kingdom [GC], quoted above, paragraph 123.

66 ECtHR. Adolfv. Austria, application no. 8269/78, judgement of 26 Mar 1982.
} 
the applicant for allegedly having thrown a bunch of keys at the victim. The proceedings initiated against Mr Adolf were terminated on the ground that both the injury allegedly caused by Mr Adolf and his fault were insignificant.

The Court focused on only one of the three criteria enounced in Engel the classification under domestic legislation - and concluded that Article 6(1) ECHR was applicable because domestic legal rules should be examined in the light of the object and purpose of Article 6(1) ECHR, namely the protection of the rights of defence. ${ }^{67}$

The applicability of the right to a fair trial was also at issue in another early case in which the applicant was involved in a car accident that resulted in the damage of two vehicles. ${ }^{68}$

The German Government argued that Article 6(1) ECHR was not applicable in the case at issue because the applicant was not charged with a criminal offence due to the decriminalization of petty offences, including road offences.

The Court, relying on the position of the German Constitutional Court, noted that the member states were free to alleviate their criminal courts of the task of dealing with numerous petty offences. However, the Court also stressed that "conferring the prosecution and punishment of minor offences on administrative authorities is not inconsistent with the Convention, provided that the person concerned is able to bring any decision thus made against him before a tribunal that does afford the safeguards of Article 6".69

By a fourteen-to-three vote, the Court concluded that Article 6(1) ECHR was applicable to decriminalized road offences. Judge Thor Vilhjalmsson made a declaration explaining his change of views from non-applicability to applicability of Article 6(1) ECHR. ${ }^{70}$

In Lauko, the Court had occasion to consider if minor offences were covered by the protection granted by Article 6(1) ECHR. ${ }^{71}$ There the applicant was accused of causing a nuisance and fined 300 Slovakian korunas.

When the applicant complained about the partiality of the criminal proceedings initiated against him, the Government disputed the applicability of Article 6 to the proceedings at issue. It argued that the present case should be distinguished from other cases decided by the Court since it involved an offence of a minor nature that could not lead to imprisonment.

\footnotetext{
$67 \quad$ Adolfv. Austria, quoted above, paragraph 3 o.

68 ECtHR. Lutz v. Germany [GC], application no. 9912/82, judgement of 25 Aug 1987.

$69 \quad$ Lutz v. Germany [GC], quoted above, paragraph 57.

70 Dissenting opinion in ECtHR. Öztürkv. Turkey, application no. 22479/93, judgement of 28 Sep 1999 .

71 ECtHR. Lauko v. Slovakia, application no. 26138/95, judgement of 2 Sep1998.
} 
The Court argued however that the fact that an offence is not punishable by imprisonment is not decisive for the purpose of the applicability of Article 6(1) ECHR as "the lack of seriousness of the penalty at stake cannot deprive an offence of its inherently criminal nature." ${ }^{72}$

As with disciplinary proceedings, petty offences in Europe often concerned disputes that have previously been decriminalised. As the case-law described above indicates, the decriminalization process has been accompanied by a tendency to limit fair trial guarantees. In this context, the ECtHR invited the member states to look beyond the appearances and the names of procedures and to ensure that the right to a fair trial was guaranteed when individuals were affected by proceedings.

\subsubsection{Economic Offences}

In the early case of Deweer, the Court considered the meaning of the notion of a "criminal charge" within the context of a criminal investigation for an economic offence. ${ }^{73}$ The applicant in this case was a retail butcher who was visited by an official of the Economic Inspectorate General who found that the meat the applicant was selling was overpriced. A few days later, the Louvain Procureur du Roi ordered the provisional closure of the applicant's shop within forty-eight hours from notification of the decision. The decision stipulated that the closure was to come into effect after the payment of 10,000 Belgian Franks by way of a friendly settlement, or on the date on which a judgement was passed on the offence.

The applicant lodged a complaint at the ECtHR complaining about the imposition of a fine by way of settlement, under constraint of provisional closure of his establishment.

The issue concerning the applicability of Article 6(1) ECHR to the present proceedings was not raised by the Belgian government. The Court raised this issue, however, out of its own motion because the applicant was not arrested, no official notification of impending prosecution was issued and no criminal proceedings had been initiated against the applicant. In fact, the criminal proceedings against the applicant have been barred by the payment of the 10,000 Belgian Franks fine as a friendly settlement. As such, no formal criminal charge had been formulated against the applicant.

However, "the prominent place held in a democratic society by the right to a fair trial" prompted the Court to prefer a "substantive", rather than a "formal",

72 Lauko v. Slovakia, quoted above, pargraphs $56^{6}-59$.

73 ECtHR. Deweer v. Belgium, application no. 6903/75, judgement of 27 Feb 1980. 
conception of the "charge" contemplated by Article 6(1) ECHR and "to look behind the appearances and investigate the realities of the procedure in question". ${ }^{74}$ Thus, a detailed analysis of the wording used by the relevant Belgian legislation and in the documents issued in the applicant's case suggested that the terms employed were criminal in nature: "offence", "offender", "gravity", "heavy penalties", "confession", "flagrant offence" and "guilt".

The Court unanimously concluded that

there accordingly exists a combination of concordant factors conclusively demonstrating that the case has a criminal character under the Convention. The "charge" could for the purposes of Article $6 \S 1$ be defined as the official notification given to an individual by a competent authority of an allegation that he has committed a criminal offence. ${ }^{75}$

A Swedish case concerned tax reports imposed on the applicant companies' taxes and additional tax surcharges. ${ }^{76}$ Despite the fact that the applicants challenged the decisions and that the judicial review of the decision was on-going, they had to pay the taxes and the surcharges imposed on them.

Referring to the Ferrazzini case, the Swedish Government argued that tax disputes fell outside the scope of Article 6(1) ECHR, and the provision was thus not applicable to the proceedings at issue.

The Court agreed that, while Article 6(1) ECHR was not applicable to tax disputes, the situation was different in the case of tax surcharges. Tax surcharges were not criminal penalties, but rather administrative sanctions.

Concerning the nature of the conduct imputed to the applicant, the Court noted that the two companies were found guilty of supplying incorrect information on their tax returns. The tax returns were imposed in accordance with the tax legislation directed towards all persons liable to pay taxes in Sweden, not towards a limited group of people.

What distinguished tax surcharges in this case was the threat of a considerable financial penalty for non-compliance. It is true that the surcharges were imposed on objective grounds only. However, the Court concluded that "the lack of subjective elements does not necessarily deprive an offence of its criminal character". ${ }^{7}$

74 Deweer v. Belgium, quoted above, paragraph 44.

75 Deweer v. Belgium, quoted above, paragraph 45-47.

76 ECtHR. Västberga Taxi Aktiebolag and Vulic v. Sweden, application no. 36985/97, judgement of 23 Jul 2002. Västberga Taxi Aktiebolag and Vulic v. Sweden, quoted above, paragraph 79. 
The same conclusion was reached by the Court in Janosevic, where the Court found that tax surcharges - which under Swedish law, had no upper limits - were not intended as pecuniary compensation incurred as the result of the taxpayer's fault, but rather "to exert pressure on taxpayers to comply with their legal obligations and to punish breaches of those obligations". ${ }^{78}$

In a follow-up case, the Court acknowledged the importance of tax to the well-being of the State. However, the Court was not convinced that "removing procedural safeguards in the imposition of punitive penalties in that sphere is necessary to maintain the efficacy of the fiscal system or indeed can be regarded as consonant with the spirit and purpose of the Convention". ${ }^{79}$

The Court further analysed the issue of the gravity of the criminal charge in the recent case of Dubus s.A. ${ }^{80}$ In this case, the applicant company was subject to an inspection from the Banking Commission, as a result of which a disciplinary investigation was initiated against the applicant and an official warning (blâme) was issued.

The applicant complained about the lack of independence of the Banking Commission, alleging that the Commission assumed both the investigation and judgement functions. The French Government argued that the official warning inflicted on the applicant had no pecuniary consequences and should not be deemed a criminal charge.

The Court observed that even if the actual sanction imposed on the applicant was an official warning, the potential sanction that the applicant could have incurred was the striking off from the Companies' Register and/or a pecuniary sanction equal to its minimum capital. The Court considered that the "criminal pigmentation" of the sanction depended in the first place on the potential sanction, not on the sanction actually inflicted, and concluded that Article 6(1) ECHR was applicable to the proceedings at issue.

Economic law is a feature of modern law, covering inter alia the functioning of markets, banks and tax surcharges. Despite the member states' argument that such disputes concerned the exercise of sovereign power, the ECtHR refused to create a separate legal regime for them. The ECtHR acknowledged their importance for the economic development of a state, but argued that when economic law disputes arose, they should be covered by Article 6(1) ECHR.

78 ECtHR. Janosevic v. Sweden [GC], application no. 34619/97, judgement of 23 Jul 2002.

79 ECtHR. Jussila v. Finland [GC], application no. 73053/o1, judgement of 23 Nov 2006, paragraph 36 .

8o ECtHR. Dubus s.A. v. France, application no. 5242/o4, judgement of 11 June 2009. 


\subsubsection{Competition Law Proceedings}

The Court has had occasion to analyse the applicability of Article 6(1) ECHR to national competition proceedings.

In the case Société Stenuit, the applicant was accused by the Minister of the Economy and Finance of having entered agreements dividing markets with other competitors and was ordered to pay 50,0oo French Francs. ${ }^{81}$ The applicant lodged a request seeking to benefit from the amnesty law of 14 August 1981. This request was rejected by the Minister of the Economy and Finance on the grounds that the applicant was guilty of administrative, not criminal offences.

The applicant company complained under Article 6(1) ECHR about a breach of their right of access to a tribunal in that the French authorities refused to apply the amnesty provisions in their case.

Since the applicability of Article 6(1) ECHR to the present proceedings was disputed between the parties, an in-depth analysis of the issue was performed first by the Commission, then by the Court.

The Commission started its analysis by highlighting the findings of the Conseil d'Etat that the fine inflicted on the applicant company was administrative, not criminal in nature. The indications provided by the domestic legislation having a relative importance, the Commission then focused on the other two Engel criteria.

First, the terms used by the French authorities belonged to the field of criminal law more than they did to administrative law. "Crime" and "offender" were only a few examples used by the French competition authorities in a field they claimed to be "administrative".

Second, the fine imposed on the applicant company - 50,00o French Francs - but also the maximum potential fine of $5 \%$ from their annual turnover, undoubtedly had a dissuasive effect.

The Commission concluded that the criminal character of the fine can be undoubtedly deducted from the "body of concordant indications" and not from a unique criterion.

The Court did not have a chance to offer its insights in this case as the French Government and the applicant company reached a friendly settlement and the proceedings ceased. ${ }^{82}$

In a case against the Netherlands, the applicant company was subject to a search of its premises in 1982. The public authorities confiscated the applicant's

81 ECtHR. Société Stenuit v. France (dec.), application no. 11598/85, judgement of 11 Jul 1989.

82 ECtHR. Société Stenuit v. France, application no. 11598/85, judgement of 27 Feb 1992, Series A no. 232-A. 
administration documents as there was a suspicion that the applicant was drawing false invoices. In 1985, the applicant was informed that the judicial proceedings initiated were to be terminated due to the time that had lapsed since the alleged offence was committed. However, despite the requests, the administration documents of the applicant's company were only returned to it in 1987 .

In 1990, the applicant lodged a complaint against the state seeking compensation for the action of the police in 1982, when they were subjected to the search. The Dutch judicial authorities held that the state was indeed liable for damages, but refused to award them due to statements made by the applicant's managing directors that false invoices had indeed been drawn up.

The applicant company complained under Article 6(2) ECHR about the refusal of the Dutch authorities to award them damages, despite the fact that criminal charges had been dropped.

It is interesting to note that in the present case the Government of the Netherlands did not invoke the inapplicability of Article 6(1) ECHR to the proceedings at hand. The Court assumed that the right to a fair trial applied to legal persons in the same way as it did to natural persons, but found that the applicant's complaint was manifestly ill-founded. ${ }^{83}$

In the case of Fortum Corporation, the applicant company was the subject of proceedings initiated by the Competition Council with a view to cease the abuse of its dominant position on the market for motor engine fuel. ${ }^{84}$ The Competition Council imposed on the applicant a fine of 336,000 EUR.

The applicant company complained that it had been denied a fair hearing in that the memoranda submitted by the Competition Council to the courts had not been communicated to it for possible comments.

The Finnish Government did not contest the applicability of Article 6(1) ECHR to the present competition law proceedings. The Court unanimously found that Article 6(1) ECHR was applicable under its criminal head and, on the merits of the case, found a violation of the right to a fair hearing. Also, the Court found that the finding of violation constitutes in itself sufficient just satisfaction for the non-pecuniary damage sustained by the applicant company.

Another case in which the Government recognised that domestic competition law proceedings belonged to the criminal sphere of Article 6(1) ECHR was Lilly France S.A. ${ }^{85}$ The Court found in this case that the lack of communication

83 ECtHR. Aannemersbedrijf Gebroeders Van Leeuwen B.V. v. the Netherlands (dec.), application no. 32602/96, judgement of 25 Jan 2000.

84 ECtHR. Fortum Corporation v. Finland, application no. 32559/96, judgement of $15 \mathrm{Jul} 2003$.

85 ECtHR. Lilly France S.A. v. France, application no. 53892/oo, judgement of 14 Oct 2003. 
of the report drafted by the adviser of the Cour de Cassation to the applicant, while the same report was communicated to the defence, infringed Article 6(1) ECHR. ${ }^{86}$

In a case against the Russian Federation, an investigation was initiated against the applicant companies by the officials of the Ministry for AntiMonopoly Policy and Business Support ("TU MAP") for concerted practices aimed at increasing prices on the fuel market. ${ }^{87}$ The applicant companies were ordered to pay back the profit obtained as a result of the breach.

The applicant companies complained that they had no access to the prosecution files during the investigation and the trial. The Government of the Russian Federation contended that Article 6(1) ECHR was not applicable under its criminal head in this case due to the fact that the applicants' case was decided by commercial courts, not by criminal courts.

The Court started its assessment by noting that the Convention case-law did not contain "explicit conclusions" that competition law offences should be regarded as criminal within the meaning of Article 6(1) ECHR. Invoking the Engel test, the Court found that, even if the individuals responsible for competition law breaches - such as the managers of the companies under investigation - could bear criminal responsibility, this did not render the investigation criminal in nature.

As to the nature of the offence, the Court noted that Russian competition law applied only to relations which influence competition in commodity markets and was of a restricted, not universal, application. Also, the Court held that the powers of the competition authorities were aimed at prevention and restoration of disturbances, not at punishment or deterrence.

Turning to the last of the Engel criteria - the severity of the potential sanction - the Court noted that Russian competition law did not provide for any specific sanctions as such. Offenders nevertheless had to comply with the orders of TU MAP. These orders could range from a simple warning to cease monopolistic activity to compulsory division of the company. In the Court's opinion, these powers of the TU MAP and the power to confiscate the unlawfully gained profit belonged to the regulatory field.

In light of the above, the Court, by majority, concluded that Article 6(1) ECHR was not applicable in the present case.

86 Lilly France s.A. v. France, quoted above, paragraph 26.

87 ECtHR. ooo Neste St. Petersburg, zao Kirishiavtoservice, ooo Nevskaya Toplivnaya, zaO Transservice, oоo Faeton, ооо PтK-Service v. Russia (dec.), application nos 69042/o1, 6905o/o1, 69054/o1, 69055/o1, 69056/o1 and 69058/o1, judgement of 3 Jun 2004. 
A few years later, the Court provided "explicit conclusions" as to the applicability of Article 6 to competition law proceedings. Thus, in the famous Menarini case, the Court applied the Engel criteria and found unanimously that Article 6 was applicable to competition law proceedings. ${ }^{88}$

Competition law cases receive more attention than other cases at the ECtHR. This might be due to the fact that the interpretation offered by the ECtHR to such cases is directly relevant for EU competition law. Indeed, the Menarini case has been cited by the CJEU and widely covered by academics. Despite this increased public scrutiny, the ECtHR applied the same standard of interpretation to competition law disputes as in other cases. Applying the Engel criteria, the ECtHR highlighted that Article 6(1) ECHR was applicable under its criminal head to competition law disputes, irrespective of the domestic qualification of the case.

88 ECtHR. A. Menarini Diagnostics S.R.L. v. Italy, application no. 43509/o8, judgement of 27 Sep 2011. 